Ser ot onergi c regul at i on of the spi nal cord cont ent of thyr ot ropi $n$ rel easi ng hor mone i $n$ the cer ebel I ar at axi a mit ant mouse

\begin{tabular}{|c|c|}
\hline 著者 & 遠藤 茂樹 \\
\hline 杂隹誌名 & 浜松医科大学学報. 学位授与記録 \\
\hline 巻 & 11 \\
\hline ページ & $162-164$ \\
\hline 発行年 & $199403-08$ \\
\hline URL & ht t p: //hdl . handl e. net /10271/1455 \\
\hline
\end{tabular}


学位論文の内容の要旨及び論文審査の結果の要旨

\begin{tabular}{|c|l|l|l|}
\hline 学位記番号 & 医博論第 178 号 & 学位授与年月日 & 平成 6 年 3 月 8 日 \\
\hline 氏 名 & 遠 藤 茂 樹 \\
\hline 論文題自 & $\begin{array}{l}\text { Serotonergic regulation of the spinal cord content of thyrotropin } \\
\text { releasing hormone in the cerebellar ataxia mutant mouse } \\
\text { (Rolling mouse Nagoya の脊髄内 TRH に対するセロトニン系調節異 } \\
\text { 常) }\end{array}$ \\
\hline
\end{tabular}




\section{医学博士遗藤茂樹 論文題目}

Serotonergic regulation of the spinal cord content of thyrotropin releasing hormone in the cerebellar ataxia mutant mouse

(Rolling mouse Nagoya $の$ 脊艏内TRHに対するセロトニン系調節異常)

\section{的侖 文 内容 の要旨}

サイロトロピン放出ホルモン（thyrotropin releasing hormone：TRH）は甲状腺刺激ホルモン 分议作用を有する視床下部ホルモンであるが、中枢神経系においては特に檤線核から脊銪に下行する ニューロン中にセロトニン（５HT）やサブスタンス P と共存しており、神経伝達物質あるいはその修 飾因子と考えられている。Rolling mouse Nagoya (RMN) はヒトの脊䯣小脳变性症のモデル動物 とされるが、TRH の投与が症状を改善することが知られており、畄および脊艏内 TRH 含量が対照、 ウスに比して多く、かつセロトニンや種々のアミン投与による脊艏内 TRH の変動が異なることが報告 されている。そこで RMN の脊䯣内 TRH に対するセロトニン系の調節異常をより明らかにするた め、セロトニンの搭抗剤やセロトニン受容体に特翼性を有するとされる種々の拮抗剤を用い、脊䯣内 TRHに及ぼすこれら莱郕の影絮を検討した。

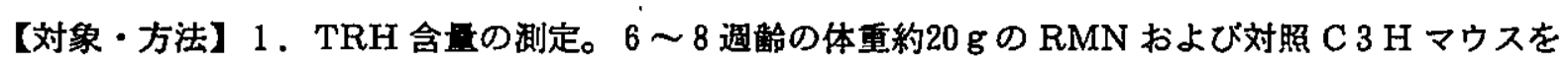
使用した。方法は体重kgあたり、セロトニンの前駆体である $5 \mathrm{HTP}$ ( 5 -hydroxytryptophan) 500 mg、アナログである 2-methyl-5 HT 100mg、セロトニンの拮抗剤として PCPA (parachlorophenylalanine) 150mg、5.7DHT (5.7dihydroxytryptamine) 300mgを、セロトニン受容体の拮抗刜として methysergide $10 \mathrm{mg}$ 、mianserin 50mg、ketanserin 50mg、spiperone 50mg、ICS205-930 $1 \mathrm{mg}$ をマウ スの腹腔内に投与、 1 時間後に等蹃を摘出した。エタノールで TRH を抽出しラジオイムノアッセイ法 にて TRH 含量の測量を行った。2.TRH 不活化能の検討。脊梿ホモジェネートに合成 TRH を添加 し経時的に抽出して TRH を测定し回収率を計算した。3，セロトニン受容体の测定。脊䯣を摘出しホ モジェネート後超遠心法にて粗膜分画を得た。 ${ }^{3} \mathrm{H}-5 \mathrm{HT}$ および $\mathrm{H}-\mathrm{ketanserin}$ を用いラジオレセプ ターアッセイ法を行った。

【結果】 1。TRH 含量の検討。(1)セロトニンおよびアゴニストの影畒 : 5 HTP および 2 -methy- 5 HT の投与にて対照群 (C $3 \mathrm{H})$ では TRH 含量の有意の增加を認めたのに対し、RMN では不変で あった。(2)セロトニン拮抗剤の影謷 :PCPA の投与により対照群では TRH 含量の有意の隇少を示した が、RMNにおいては脊髄の全部位において有意の増加を示した。5.7DHT の投与では対照群、RMN 両群において TRH 含量の有意の減少を認めた。(3)セロトニン受容体の拮抗剤の影传：対照群において は methysergide, mianserin, ketanserin および spiperone の投与により TRH 含量は有意の減少 を示したが、ICS205-930の投与では不変であった。一方これらの拮抗剤の投与は RMNにおいては頚 随での TRH 含量の有意の增加を示した。(4) 脊随における TRH 不活化能の検討 : 脊髅のホモジェ ネートによる TRH の不活化能 (T 1／2）はC $3 \mathrm{H} 、 \mathrm{RMN}$ 両群間で有意差を認めなかった。2. 脊 随のセロトニン受容体の険討。Scatchard 解析により $\mathrm{kd}$ および Bmax を計算したが C $3 \mathrm{H} 、 \mathrm{RMN}$ 両群間で差を認めなかった。

【考察】セロトニンは脊随内 TRH を調節している可能性があり、対照群における答髄内 TRH はセ口 トニンおよびアコニストにより增加を示し、セロトニンの拮抗物質およびセロトニン受容体拮抗郕によ 
り対照群で減少を示した。これに対し RMN ではセロトニンおよびアゴニストにより脊能内 TRH の变動 がみられず、拮抗剤により逆に增加する傾向を認めた。現在までにセロトニンの受容体は $5 \mathrm{HT}$ 、 $5 \mathrm{HT}_{2}$ および $5 \mathrm{HT}_{3}$ が知られており、脳や脊蹃における分布が示されている。今回の検討では、各 受容体に対する反応性が RMN においては正常対照群とは貲なっていた。以上より、RMNでは春䯣 内 TRH レベルがセロトニン系ニューロンにより巽常な調節を受けており、特にセロトニン受容体 $5 \mathrm{HT}_{2}$ あるいは $5 \mathrm{HT}$,に関連していると考えられた。

\section{論文謇 查の結果の要旨}

サイロトロピン放出ホルモン（thyrotropin releasing hprmone,TRH）は甲状腺刺激ホルモン分 汹作用を有する視床下部ホルモンとして知られている。しかし、脳の他の部位、脊艏前根、三叉神経な ど脳神経にも広く分布し、神程伝達物質あるいはその修飾茵子としての役割も推定されている。特に繾 線核から脊髄に下行するニューロン中にセロトニン（５HT）やサブスタンス P と共存していることが 注目される。

ヒト脊随小脳変性症のモデル動物とされている。 Rolling mouse Nagoya では、TRH の投与によ り庭状が改善することが知られており、また、脳内および脊随中の TRH 含量が多いことや、 5 HT 等 種々のアミンの投与による脊能内 TRH の変動が対照マウスと異なることが報告されている。そこで申 請者は、Rolling mouse Nagoyaにおける5 HT 系による龫髄 TRH の調節異常により明らかにする

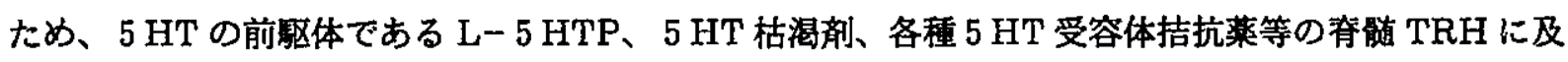
ぼす影警を挨討した。体重約20 g の Rolling mouse Nagoya および対照 C 3 H マウスにこれら莱郕 を投与（i. p.) し、1 時間後に脊髄の TRH を㣜定した。

実験の結果、対照群では脊艏 TRH は、L- 5 HTP および 5 HT アゴニスト (2-methyl- 5 HT)

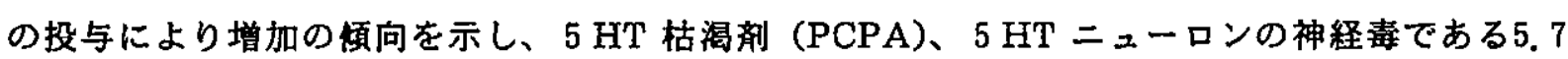
-DHTおよび $5 \mathrm{HT}$ 受容体拮抗莯（5 HTs 拮抗莱である ICS205-930を除く）により減少した。一方、 Rolling mouse Nagoyaでは、L-5 HTP、2-methyl-5 HTにより脊䯣 TRH の変動がみられず、 PCPA 投与によりむしろ增加し、5 HT 受容体拮抗薬によっても預髄の TRH 含量は有意に增加した。奉 髄ホモジネート中での TRH の消失の速度や脊髄粗膜分画への ${ }^{9} \mathrm{H}-5 \mathrm{HT} 、{ }^{3} \mathrm{H}-$ Ketanserin 結合の Kd、Bmaxには対照マウスと Rolling mouse Nagoya間に有意な差はなかった。申請者は以上の結果 に基づいて、Rolling mouse Nagoya では脊髄内 TRH レベルは $5 \mathrm{HT}$ 系ニューロンにより異常な調節 を受けていると考えた。

番查委員会では、本論文の内容の関連して次の武問を行った。

1. Rolling mouse Nagoyaの由来、C $3 \mathrm{H}$ を対照に選んだ理由

2. PCPA（p-クロロフェニルアラニン）投与後の脊髄トリプトファン水酸化酻素活性と $5 \mathrm{HT}$ 含量 の低下およびそれに引き続く回復の時間経過

3. L- 5 HTP 投与後の㾞璡 $5 \mathrm{HT}$ 增加の程度と時間経過

4. 2-methyl- 5 HT 投与の血圧に対する影籍、これを介して reflex が起こる可能性

5.5 HT 受容体サブタイプの種類および個々のサブタイプの構造之機能、繾線核から脊髄への $5 \mathrm{HT}$ ニューロンで自己受容体として機能している $5 \mathrm{HT}$ 受容体サブタイプ、個々の $5 \mathrm{HT}$ 受容体拮抗莱 のサブタイプ特異性等

6. Rolling mousu Nagoya でL- 5 HTP や 2-methyl- 5 HT の投与とは無関係に胸鰱の TRH 含 
量が対照ラットより著しく高いことに対する申請者の見解

7. 脊餚における TRH の存在部位、合成部位、輸送および分泌機樓、作用機構、分解機構

これらの質問に対する申請者の応答は概ね適切と認められ、本論文が博士（医学）の学位授与に値す る内容を備えていると全員一致で判定した。

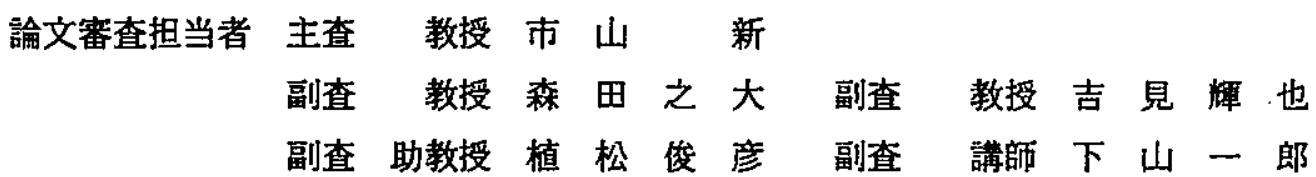

